\title{
The impact of entrepreneurship education on the entrepreneurial intention of students in science and engineering versus business studies university programs
}

\author{
Daniela Maresch a , Rainer Harms ${ }^{\mathrm{b}, *}$, Norbert Kailer $^{\mathrm{c}}$, Birgit Wimmer-Wurm ${ }^{\mathrm{c}}$ \\ a Institute for Innovation Management, Johannes Kepler University Linz, Austria \\ b IGS/NIKOS, University of Twente, The Netherlands \\ c Institute for Entrepreneurship and Organizational Development, Johannes Kepler University Linz, Austria
}

\section{A R T I C L E I N F O}

\section{Article history:}

Received 30 September 2014

Received in revised form 13 May 2015

Accepted 3 November 2015

Available online 23 December 2015

\section{Keywords:}

Entrepreneurship education

Entrepreneurial intention

Student entrepreneurship

Technology entrepreneurship

Theory of planned behavior

TPB

\begin{abstract}
A B S T R A C T
Academic research has shown that Entrepreneurship Education (EE) increases Entrepreneurial Intention (EI). However, this does not happen uniformly in all contexts, as specific contexts may require different EE action. In this paper the authors investigate the context-specific questions in two separate categories of students. If context is important, we should see different outcomes from similar EE classes provided to different student groups. The authors' results suggest that there is a contextual difference. The results indicate that EE modified to suit a particular target group could address the issue of subjective norms separately for business students and science and engineering students. Their principal results show that EE is generally effective for business students and science and engineering students. However, the EI of science and engineering students is actually negatively affected by subjective norms, whereas that effect is not apparent among the business student sample. The authors suggest that future research is needed on effective didactic approaches in EE for science and engineering students.
\end{abstract}

(C) 2015 Elsevier Inc. All rights reserved.

\section{Introduction}

The importance of entrepreneurship to society has been identified and discussed since at least the fifteenth century (Schumpeter, 1912), and that discussion remains topical (Kirchhoff et al., 2013; Grichnik and Harms, 2007). The questions of whether and how entrepreneurial skills and competences can be fostered during education were posed by Cotrugli (1990), and later followed up by Cantillon (1931). From these historical roots, Entrepreneurship Education (EE) has evolved to become a prominent field. This field is born of diverse disciplines, which include economics, management, education, and technical studies (Davidsson, 2008).

The authors embrace the concept that EE is based on the realization that successful entrepreneurship is positively affected by the dispositions, skills, and competences of the founders of an enterprise (Rauch et al., 2005; Unger et al., 2011). We suggest that these dispositions, skills, and competences can be shaped by education (Kuratko, 2005), and cite recent meta-analyses (Bae et al., 2014; Martin et al., 2013) indicating that EE is generally effective. We seek to enhance the knowledge in this field by investigating the outstanding question of what makes EE effective, and for whom.

\footnotetext{
* Corresponding author.

E-mail addresses: daniela.maresch@jku.at (D. Maresch), r.harms@utwente.nl (R. Harms), Norbert.kailer@jku.at (N. Kailer), birgit.wimmer-wurm@jku.at (B. Wimmer-Wurm)
}

The question of "what makes EE effective" has been discussed in a literature stream on intention-based models for entrepreneurship education (Kuehn, 2008). Kuehn (2008, p. 87) states: "If entrepreneurial intentions precede entrepreneurial behavior, then entrepreneurship educators should benefit from intentions-based research in entrepreneurship". If this is so, then EE should investigate the drivers of this Entrepreneurial Intention (EI). Theory, and a recent meta-analytical assessment (Schlaegel and Koenig, 2014), both suggest that the drivers of El are attitudes, subjective norms, and perceived behavioral control. These elements of the Theory of Planned Behavior (TPB) also influence the effectiveness of EE (Kuratko, 2005; Gorman et al., 1997; Rauch and Hulsink, 2015).

EE research further investigates when EE can most effectively influence students' EI. We analyze two such conditions. First, we examine the extent to which students possess the attitudes, subjective norms, and perceived behavioral control considered prerequisites of becoming an entrepreneur. Here we add to the literature by investigating not only the direct effects of TPB constructs, but, in treating them as moderators of the EE-EI relationship (Ho et al., 2014), and we also examine the relationship in the context of specific fields of study.

Second, it is science and engineering students in particular whose entrepreneurial activities create new, high-quality firms (Åstebro et al., 2012) that ultimately contribute to job growth (Kirchhoff, 1994). Strengthening this human capital basis for technology-based entrepreneurship may be vital, especially for regions affected by an economic crisis (Harms et al., 2010; Heitor et al., 2014; Fink et al., 2012). 
However, with few exceptions (Phan et al., 2009; Yanez et al., 2010), the literature on the EE offered to science and engineering students is quite thin. We address the call from Rauch and Hulsink (2015) for more research into the specific effects of EE programs on students from different disciplines, particularly from science and engineering disciplines. We investigate the specific situation of students of technical sciences, as they are the most likely to start up technology-oriented ventures. Our analysis is relevant as it shows which drivers in which target groups educators can address to nurture EI.

\section{Theoretical framework and hypotheses}

\subsection{Affecting entrepreneurial intention through entrepreneurship education - a discussion of the literature}

We refer to the definition of EI as the "self-acknowledged conviction by a person that they intend to set up a new business venture and consciously plan to do so at some point in the future" (Thompson, 2009, p. 676). EI has become a vibrant field in entrepreneurship research (Fayolle and Linan, 2014), as "intentions have proven the best predictor of planned behavior, particularly when that behavior is rare, hard to observe, or involves unpredictable time lags" (Krueger et al., 2000, p. 411). Most recently, a longitudinal study by Kautonen et al. (2015) confirmed that EI predicts entrepreneurial action. Thus, the question of what influences $\mathrm{EI}$ is a relevant one for policy makers, practitioners, and educators.

Research into the role of EE in the formation of EI is based, first of all, on TPB (Ajzen, 1991), which provides a strong theoretical foundation (Schlaegel and Koenig, 2014; Krueger and Carsrud, 1993). It posits that a person's future behavior is preceded by intention: the stronger a person's intention to engage in a specific behavior, the more likely it is that the actual behavior will be performed. Furthermore, the intention to perform a given behavior is the result of three cognitive antecedents: (i) attitude toward behavior; (ii) subjective norms; and (iii) perceived behavioral control.

Second, EE is seen as a strong antecedent of EI. Two theoretical concepts have been developed that support this relationship: (i) human capital theory (Becker, 1964); and (ii) entrepreneurial self-efficacy (Bae et al., 2014; Chen et al., 1998). Human capital theory holds that human capital represents "the skills and knowledge that individuals acquire through investments in schooling, on-the-job training, and other types of experience" (Bae et al., 2014, p. 219-220). It is regarded as a determinant of EI. A meta-analysis by Martin et al. (2013) found that EE is associated with higher levels of EI. Entrepreneurial self-efficacy refers to "the strength of a person's belief that he or she is capable of successfully performing the various roles and tasks of entrepreneurship" (Chen et al., 1998, p. 295). Chen (2010) found entrepreneurial self-efficacy to be a positive moderator of the relationship between EE and EI.

Research on EI has brought together TPB and EE in various ways (Martin et al., 2013). In earlier studies, education was merely the context in which TPB constructs and EI were evaluated (Autio et al., 2001; Liñán, 2004; Lüthje and Franke, 2003). Apart from the direct effects of EE on EI, another group of studies assumes that the effect of EE on EI is (partially) mediated through its effect on TPB's intervening constructs (Rauch and Hulsink, 2015). As the direct and mediated influences of EE via TPB have meta-analytical support, research has begun to investigate a fourth model variant, which is that the effect of EE on EI may be moderated by the three cognitive antecedents posited under TPB (Ho et al., 2014).

In this study we provide an integrated model of the relationship between EE and EI that brings together both direct and indirect effects. The following section reports the development of the hypotheses.

\subsection{Hypotheses}

We begin by hypothesizing a direct impact of TPB constructs on EI, based on the findings of previous studies (Krueger et al., 2000; Kautonen et al., 2015; Lüthje and Franke, 2003; Kolvereid, 1996;
Souitaris et al., 2007). We add to the literature by providing hypotheses on why this impact may differ between science and engineering students and other students.

First, the term 'attitudes toward behavior' refers to a person's favorable or unfavorable evaluation of the target behavior. The more positive a person's evaluation of the outcome of starting a business is (Krueger et al., 2000; Autio et al., 1997; Pruett et al., 2009; Segal et al., 2005; Van Gelderen and Jansen, 2008), the more favorable his or her attitude toward that behavior should be, and consequently the stronger his or her intention to start a business should be. Second, the term 'subjective norms' relates to a person's perception of the opinions of social reference groups (such as family and friends) on whether the person should perform a certain behavior. The better the reference group's opinion is, the more encouragement for starting a business a person receives from this reference group, and the higher the person's motivation to comply with it is, the stronger the person's intention to start a business should be. Third, the term 'perceived behavioral control' reflects the perceived ease or difficulty of performing the behavior. It is based on whether the person believes that the required resources can be obtained, and that opportunities for performing the behavior exist (Bandura, 1986; Swan et al., 2007). Perceived behavioral control not only predicts the formation of intentions, but also supports the prediction of actual behavior by serving as a proxy for actual control (Ajzen, 1991).

In the context of entrepreneurship, the empirical results broadly confirmed TPB predictions with respect to the positive relationship between attitudes toward behavior, subjective norms and perceived behavioral control, respectively, and EI (Krueger et al., 2000; Kautonen et al., 2015; Lüthje and Franke, 2003; Kolvereid, 1996; Souitaris et al., 2007). In line with these findings, we propose the following hypothesis:

H1a. There is a positive relationship between (1) pro-entrepreneurial attitudes, (2) subjective norms, and (3) perceived behavioral control, and a person's EI.

The fact that recent graduates from science and engineering are providing the gross flow of new, high-quality firms-over and above those of other academic entrepreneurs (Åstebro et al., 2012)-highlights the importance of these students as targets of EE. Thus, the fact that the majority of studies into student EI are based on business students or on undefined student populations (Bae et al., 2014; Martin et al., 2013), indicates a gap in the literature arising because this student population might differ from others with regard to entrepreneurship. This difference may be based on education content (Kuckertz and Wagner, 2010) and on social identity theory (Obschonka et al., 2012).

Business students have received more education in business matters than other students. This may cause a weakening of the relationship between pro-entrepreneurial attitudes, subjective norms, perceived behavioral control and a person's EI. Kuckertz and Wagner argue that (Kuckertz and Wagner, 2010, p. 529): "learning about the facts of business causes [business students] to evaluate entrepreneurial opportunities more vigorously". This additional knowledge may not only reduce the level of EI per se, but also the degree to which initially favorable TPB components influence EI.

Obschonka et al. (2012) draw on social identity theory. They argue that social identity - "the aspect of a person's self-image that is derived from membership of social groups" (Obschonka et al., 2012, p. 137) influences the "cognitive processes that [...] underlie the formation of entrepreneurial intentions" (Obschonka et al., 2012, p. 137). Here, Obschonka et al. (2012) show that the strength of group identification can affect the relative strength of the TPB drivers of EI. We argue that it may not only be the strength of group identification that leads to differences in the strength of TPB drivers-between business students and science and engineering students-but that the group differences themselves lead to differences in the strength of TPB drivers. For example, science and engineering students may perceive that legitimate group behavior in their case includes the exploration of science and 
engineering matters (Jungert, 2013). Hence, they may regard subjective norms relating to entrepreneurship as rather negative. This perception may lead to a weak relationship between TPB drivers and EI, particularly in the context of high group identification.

In one of the first empirical studies into EI among science and engineering students, Lüthje and Franke (2003) show that EI is significantly related to pro-entrepreneurial attitudes. Souitaris et al. (2007) show that EE can impact positively on pro-entrepreneurial attitudes of science and engineering students, a finding that was later confirmed by Kuckertz and Wagner (2010). These studies confirm the importance of $\mathrm{EE}$, and pro-entrepreneurial attitudes toward EI, for science and engineering students. So, while in general the effect of TPB components may also be applicable to business students, theoretical arguments suggest that a differentiated perspective may be warranted. This leads us to propose $\mathrm{H} 1 \mathrm{~b}$.

H1b. The degree to which pro-entrepreneurial attitudes, subjective norms, and perceived behavioral control affect EI, differ with the type of study.

In addition to these three motivational drivers, EE research proposes that there is a positive relationship between EE and EI. Robinson et al. (1991) argue that entrepreneurial attitudes may be influenced by educators and practitioners. Dyer (1994) suggests that training in how to start a business, or specialized courses in entrepreneurship, might give some people the confidence that they are sufficiently in control of their own behavior to start their own business. Similarly, Krueger and Brazeal (1994) argue that EE increases students' knowledge, builds their confidence, and fosters self-efficacy, which should, in turn, enhance their perception that entrepreneurship is a feasible option for them. Moreover, EE shows students the intrinsic rewards involved in starting a new business, which should increase the perceived desirability of entrepreneurship. In research relating specifically to science and engineering students, Souitaris et al. (2007) tested the effect of EE programs on entrepreneurial attitudes and EI, and found that science and engineering programs increase overall EI. A recent meta-analysis of the link between EE and EI (Bae et al., 2014) supports the positive link between the two. Finally, EE not only promotes entrepreneurial behavior, but also intrapreneurial behavior (Bjornali and Støren, 2012). Thus, we propose the following hypothesis:

\section{H2a. The higher the extent of EE, the stronger the person's EI.}

The strength of the impact of EE may differ between business students and science and engineering students. This study highlights two competing lines of arguments. On the one hand, the impact of EE on EI may be greater for science and engineering students than for students in other disciplines. Education might have a diminishing rate of return. It may be most effective in changing intentions when the initial level of EE is low. That might well be the case for science and engineering students, who often learn about entrepreneurship and business in detail for the first time via EE. By contrast, the incremental effects of EE on business students may be low. The findings of Frederick and Walberg (1980) indicate that the time spent on instruction may have a diminishing rate of return.

On the other hand, Walberg and Tsai (1983) argue (referencing Simon (1979)) that prior experience of a subject allows a person to acquire and process new knowledge more efficiently than those with less exposure to the subject. Hence, science and engineering students may have a different mental framework from that which is suited to quickly process information on entrepreneurship. This may make EE more effective for business students.

H2b. The degree to which EE affects a person's EI is affected by the type of study.

We now look at the moderating effects EE has on the three cognitive antecedents of EI. EE affects how students evaluate the consequences of entrepreneurship. According to Prospect Theory (Kahneman and Tversky, 1979), a certain gain is valued more highly than an uncertain equal or greater gain. Similarly, people will assess a certain loss to be more damaging than an uncertain equal or greater loss. Logically, the gains and losses induced by the same stimulus (e.g., starting a business) will be evaluated against the background of a future without that stimulus.

This expectation bias has three effects on the impact of EE on students' EI. First, as EE typically frames entrepreneurship positively in terms of gains compared against other career options, it will strengthen students' positive attitudes rather than any negative ones and therefore enhance the positive impact of attitudes on EI. As the effects proposed by Prospect Theory are expected to hold generally, we do not propose a differentiated set of hypotheses for business students and science and engineering students. We propose the following hypothesis:

H3a. The higher the extent of EE, the stronger the positive impact of attitudes on EI.

Second, the more students know about entrepreneurship, the clearer will be their expectations of how entrepreneurship will influence their lives, which in turn will make their decisions less reliant on the entrepreneurship opinions of their social reference groups (Kautonen et al., 2015).

H3b. The greater the extent of EE, the weaker the positive impact of subjective norms on EI.

Third, EE aims to help students develop the skills and competences to seize entrepreneurial opportunities. Thus, as students receive more $\mathrm{EE}$, they should become more confident in their ability to create and evaluate entrepreneurial opportunities, and in their ability to secure the resources required to seize them. This leads to potential entrepreneurship gains becoming more likely, while at the same time the losses arising from the risk involved in entrepreneurial activity become less likely. We propose the following hypothesis:

H3c. The greater the extent of EE, the weaker the positive impact of perceived behavioral control on EI.

Fig. 1 illustrates the hypothesized relationships.

\section{Method}

\subsection{Data collection and description of the sample}

The data from this study are derived from the 2011 Austrian study (Kailer et al., 2012) of the GUESSS project [Global University Entrepreneurial Spirit Students' Survey] (Sieger et al., 2011). The data for the online survey were provided by Austrian students at 23 institutes of higher education, with the express support of their senior faculty. The survey attracted 4548 responses, representing a response rate of $4.3 \%$. The allocation by field of study, as well as by the level of study, shows a distribution approximating to the Austrian student population.

When an empirical analysis is based on cross-sectional data collected with just one method (Lindell and Karagozoglu, 1997), and with the key variables captured as self-reported continuous values (Harrison et al., 1996) the threat of common method bias (CMB) cannot be discounted. CMB refers to false conclusions that result from "variance that is attributable to the measurement method rather than to the constructs the measures represent" (Podsakoff et al., 2003, p. 879, Williams and Brown, 1994). If methodical triangulation is impossible, Podsakoff et al. (2003) suggest a variety of measures to identify and correct CMB. However, according to Spector (2006) and Richardson et al. (2009), the suggested measures to protect studies from CMB are unreliable and often misleading. Thus, this study focuses on strategies that help to avoid $\mathrm{CMB}$ in the first place. To reduce evaluation apprehension, we assured that their input would be anonymous (Podsakoff et al., 


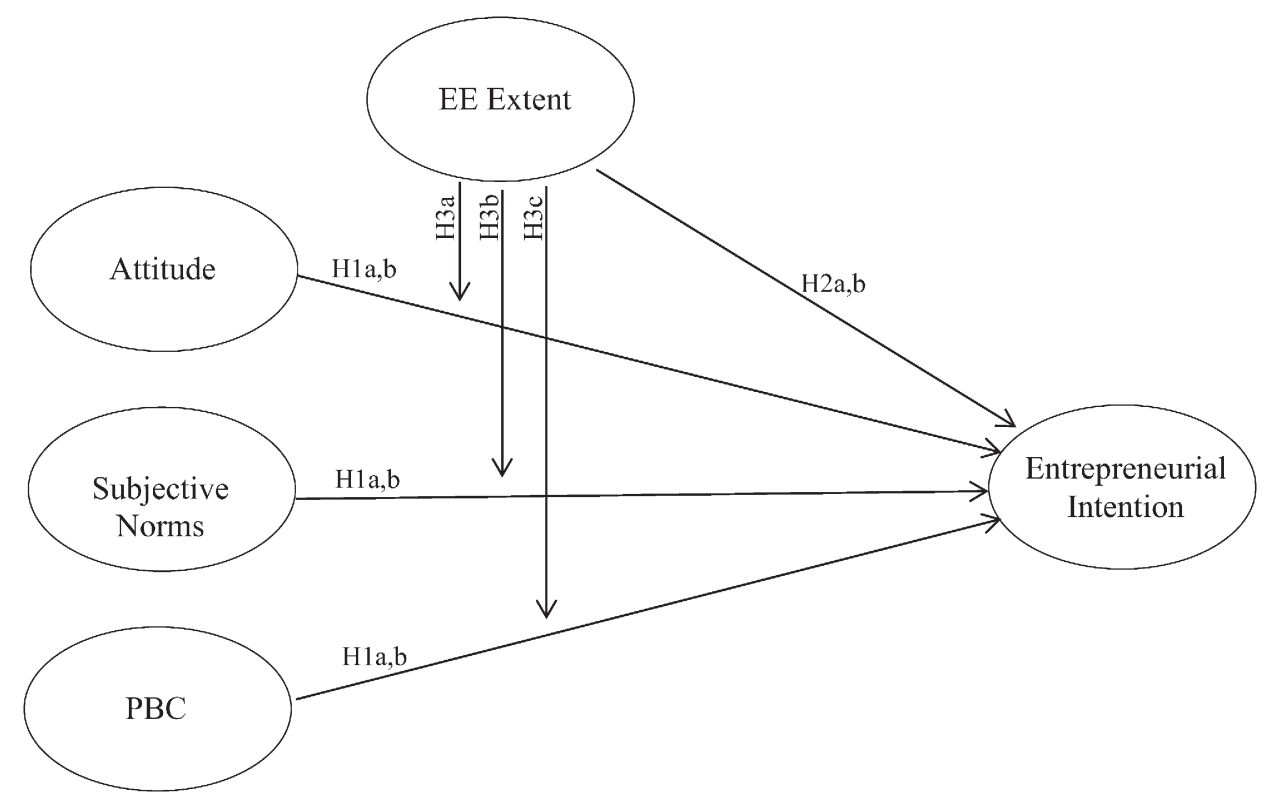

Fig. 1. Research model.

2003), and we also counterbalanced the question order in the questionnaire (Chang, 2010).

The authors took several measures to avoid nonresponse bias (NRB), including carefully designing the questionnaire, managing its length, and establishing the importance of the survey (Yu and Cooper, 1983). However, since NRB cannot be ruled out in view of the achieved return rate, we employed archival and wave analysis (Rogelberg and Stanton, 2007). The first approach helps to verify whether external factors prevented the recipient from returning the completed questionnaire on time (passive NRB), by comparing the characteristics of the sample with the characteristics of the population (Rogelberg and Stanton, 2007). The second approach looks for active NRB resulting from the recipient's conscious decision not to respond, by comparing early and late responses (Rogelberg et al., 2003). Neither of the tests suggests that NRB is an issue in this dataset.

\subsection{Operationalization and method of analysis}

Entrepreneurial Intention, as our dependent variable, was measured with a 7-point Likert scale, anchored with I never thought about founding (1), and I have already started on the realization (7). Conceptually and empirically, the measure is based on the entrepreneurial ladder (van der Zwan et al., 2012). The subsequent analysis excluded responses at the far end of the realization scale (number 7 on the Likert scale) in order to exclude actual founders of enterprises (Thompson, 2009).

Attitude was based on Ajzen (1991), and measures the respondent's attitude toward entrepreneurship. The measure used was a 7-point, 4item scale whose single factor explains $81.79 \%$ of variance. It has a Cronbach's alpha $(\alpha)$ of .925 .

The measurement of subjective norms used a 7-point scale to capture opinions on the respondent starting a business, from family, friends, and people generally important to the respondent (Kolvereid, 1996). The higher the value, the more positive was the subjective norm supporting entrepreneurship. Its single factor explains $74.14 \%$ of variance. It has a Cronbach's $\alpha$ of .821 .

Perceived behavioral control was measured in accordance with the construct of the locus of control scale by Levenson (1973). The study adopts 8-item, 7-point scale aggregated to a formative construct. While perceived behavioral control focuses on a more specific behavior (in this case a startup), the locus of control reflects a more general view on whether a person can actively influence his or her life. The locus of control is less suitable for predicting a specific behavior (Ajzen, 1991), but was part of the dataset.

Entrepreneurial education was measured by the number of entrepreneurship courses that each student had taken; examples included Business Planning, Creativity, Entrepreneurial Marketing, and others. To differentiate education tracks, we used the self-reported study specialization. Specifically, we compared students from technical disciplines (engineering and natural sciences) with students from business studies (business administration and economics). As control variables we chose age and gender.

The descriptive statistics suggest that there are few differences between science and engineering students and business students. A key difference is that science and engineering students have a higher degree of EE (Table 1).

The chosen method of analysis was ordered logistic regression, as the dependent variable was highly skewed. Group 1 contains those that had never considered an entrepreneurial career, and group 2 contains those who had considered entrepreneurship to at least some degree. Within the ordered logistic regression we took a stepwise approach, in that we first entered the controls, then the direct relationship that reflects the impact of the TPB components, and finally the moderators. Moderation is assessed with a two-way interaction of centered variables. These stepwise analyses were carried out twice, once for science and engineering students, and once for business students.

\section{Findings}

The results of the analysis are summarized in Table 2 . The $\mathrm{R}^{2}$ values and the percentage of correctly classified cases indicate a good overall model fit. The increase in $\mathrm{R}^{2}$ and the percentage of correctly classified cases from step one to step two, and finally to step three, indicate that each step contributed to explaining EI.

The control variables suggest that older students have a higher degree of EI. Female students, however, have a lower degree of EI. These findings show that the inclusion of the controls was warranted.

Pro-entrepreneurial attitudes are in all cases positively related to EI. This is in line with previous findings. Subjective norms are negatively related to EI for science and engineering students, and significant for the whole group. This finding contrasts with previous findings. Perceived behavioral control is positively related to EI for the full sample, but there is no significant relation for science and engineering students, 
Table 1

Operationalization.

\begin{tabular}{|c|c|c|c|c|c|c|c|c|}
\hline & \multirow[b]{2}{*}{ FL } & \multicolumn{2}{|c|}{ Full sample } & \multicolumn{2}{|c|}{$\begin{array}{l}\text { Science and } \\
\text { engineering } \\
\text { students }\end{array}$} & \multicolumn{2}{|c|}{$\begin{array}{l}\text { Business } \\
\text { students }\end{array}$} & \multirow[t]{2}{*}{ Diff. } \\
\hline & & Mean & SD & Mean & SD & Mean & SD & \\
\hline \multicolumn{9}{|l|}{ Control variables } \\
\hline Age & & 28.45 & 1.43 & 28.01 & 5.02 & 27.99 & 5.73 & \\
\hline Gender $(0=$ male $; 1=$ female $)$ & & 0.64 & .48 & .30 & .46 & .60 & .49 & $* * *$ \\
\hline \multicolumn{9}{|l|}{ Independent variables } \\
\hline \multicolumn{9}{|l|}{ Attitude (Cronbach's alpha $=.925 ; \%$ var. expl.: $81.79 \%$ ) } \\
\hline Being an entrepreneur suggests more advantages than disadvantages to me. & .831 & 3.98 & 1.58 & 4.16 & 1.47 & 4.28 & 1.56 & \\
\hline A career as entrepreneur is attractive for me. & .936 & 4.08 & 1.85 & 4.39 & 1.69 & 4.53 & 1.81 & \# \\
\hline If I had the opportunity and resources, I would become an entrepreneur. & .919 & 4.40 & 1.92 & 4.67 & 1.77 & 4.82 & 1.85 & \\
\hline Being an entrepreneur would bring me great satisfaction. & .927 & 3.83 & 1.90 & 4.00 & 1.83 & 4.33 & 1.86 & ** \\
\hline \multicolumn{9}{|l|}{ Subjective norms (Cronbach's alpha $=.884 ; \%$ var. expl.: $81.75 \%$ ) } \\
\hline \multicolumn{9}{|l|}{ If I became an entrepreneur, my ... would react: } \\
\hline Parents and other family members & .832 & 5.26 & 1.36 & 5.39 & 1.30 & 5.42 & 1.34 & \\
\hline Friends and other students & .880 & 5.39 & 1.19 & 5.51 & 1.11 & 5.57 & 1.12 & \\
\hline Other persons important to me & .864 & 5.40 & 1.18 & 5.46 & 1.12 & 5.56 & 1.13 & \# \\
\hline \multicolumn{9}{|l|}{ Perceived behavioral control (formative) } \\
\hline When I get what I want, it is usually because I am lucky. (r) & & 4.78 & 1.45 & 4.09 & 1.42 & 4.87 & 1.41 & \\
\hline I have often found that what will be, will be. (r) & & 3.40 & 1.54 & 3.51 & 1.54 & 3.40 & 1.52 & \\
\hline It is not always wise for me to plan too far ahead because many things turn out to be a matter of good or bad fortune. (r) & & 4.78 & 1.57 & 4.80 & 1.54 & 4.82 & 1.46 & \\
\hline My life is chiefly controlled by powerful others. (r) & & 5.59 & 1.42 & 5.56 & 1.47 & 5.65 & 1.35 & \\
\hline I feel like what happens in my life is mostly determined by powerful people. (r) & & 5.77 & 1.38 & 5.75 & 1.42 & 5.75 & 1.34 & \\
\hline In order to make my plans work, I make sure that they fit in with the desires of people who have power over me. & & 5.81 & 1.37 & 5.70 & 1.45 & 5.76 & 1.35 & \\
\hline I am usually able to protect my personal interests. & & 5.24 & 1.19 & 5.34 & 1.20 & 5.30 & 1.13 & \\
\hline $\begin{array}{l}\text { I can pretty much determine what will happen in my life. } \\
\text { Moderator variables }\end{array}$ & & 5.77 & 1.18 & 5.75 & 1.24 & 5.82 & 1.13 & \\
\hline Entrepreneurship Education (single item) & & 1.33 & 2.43 & 1.33 & 2.30 & 0.95 & 1.68 & $* * *$ \\
\hline \multicolumn{9}{|l|}{ Dependent variable } \\
\hline \multicolumn{9}{|l|}{ Entrepreneurial Intention (single item) } \\
\hline Please indicate if and how seriously you have thought about founding your own company. & & 1.66 & 1.56 & 1.87 & 1.63 & 1.82 & 1.51 & \\
\hline
\end{tabular}

(r) recoded; FL: factor loading; SD: standard deviation.

$* \mathrm{p}<.05$.

** $\mathrm{p}<.01$.

\# $\mathrm{p}<.1$.

or for business students. This gives partial support for H1a and support for H1b.

We find significant positive relations between EE and EI for all groups. This lends support to H2a. The coefficient for the business student sample is larger than the coefficient for the other groups. This finding supports $\mathrm{H} 2 \mathrm{~b}$.

Only one finding is significant with regard to the moderated relationship between EE and TPB components: the greater the extent of $\mathrm{EE}$, the weaker the positive impact of subjective norms on EI. This lends support to hypothesis H3b (Table 3).

\section{Discussion and conclusion}

The goal of this study was to analyze two sets of conditions under which EE may be most effective for enhancing EI. We analyzed the role of motivational drivers and type of prior education. We found general support for a positive effect of EE on EI. Further, we found mixed

Table 2

Correlations.

\begin{tabular}{|c|c|c|c|c|c|c|c|}
\hline & & (1) & (2) & (3) & (4) & (5) & (6) \\
\hline (1) & Age & & & & & & \\
\hline (2) & Gender & $-.144^{* *}$ & & & & & \\
\hline (3) & Attitudes & $.027^{\#}$ & $-.172^{* *}$ & & & & \\
\hline (4) & Subj. norms & $-.094^{* *}$ & -.011 & $.490^{* *}$ & & & \\
\hline (5) & $\mathrm{PBC}$ & $.074^{* *}$ & $-.069^{* *}$ & $.051^{* *}$ & $.092^{* *}$ & & \\
\hline (6) & $\mathrm{EE}$ & -.022 & $.031^{*}$ & .023 & .017 & -.013 & \\
\hline (7) & EI & $.124^{* *}$ & $-.136^{* *}$ & $.517^{* *}$ & $.252^{* *}$ & $.086^{* *}$ & $.080^{* *}$ \\
\hline
\end{tabular}

Table 3

Results of the moderated regression.

\begin{tabular}{|c|c|c|c|c|c|c|}
\hline & \multicolumn{2}{|c|}{$\begin{array}{l}\text { Full sample } \\
\mathrm{n}=3581\end{array}$} & \multicolumn{2}{|c|}{$\begin{array}{l}\text { Science and } \\
\text { engineering } \\
\text { students } \\
\mathrm{n}=635\end{array}$} & \multicolumn{2}{|l|}{$\begin{array}{l}\text { Business } \\
\text { students } \\
\mathrm{n}=859\end{array}$} \\
\hline & B & Sig & B & Sig & B & Sig \\
\hline \multicolumn{7}{|l|}{ Step 1} \\
\hline Constant & -.707 & .000 & -.385 & .465 & -.098 & .805 \\
\hline Age & .037 & .000 & .029 & .117 & .028 & .038 \\
\hline Gender & -.482 & .000 & -.527 & .007 & -.758 & .000 \\
\hline$C \& S-R^{2} ;$ Nagelk. $\mathrm{R}^{2} ; \%$ corr. class. & \multicolumn{2}{|c|}{$\begin{array}{l}.029 ; .039 \\
58.4 \%\end{array}$} & \multicolumn{2}{|c|}{$\begin{array}{l}.020 ; .027 ; \\
59.4 \%\end{array}$} & \multicolumn{2}{|c|}{$\begin{array}{l}.042 ; .056 \\
60.1 \%\end{array}$} \\
\hline \multicolumn{7}{|l|}{ Step 2} \\
\hline Constant & -.1 .474 & .000 & -.971 & .108 & -1.517 & .002 \\
\hline Age & .049 & .000 & .035 & .091 & .057 & .001 \\
\hline Gender & -.331 & .000 & -.206 & .352 & -.739 & .000 \\
\hline Attitudes & .223 & .000 & .209 & .000 & .232 & .000 \\
\hline Subjective norms & .105 & .487 & -.335 & .009 & .084 & .423 \\
\hline Perceived behavioral control & .013 & .011 & -.001 & .959 & .000 & .002 \\
\hline$C \& S-R^{2}$; Nagelk. $\mathrm{R}^{2} ; \%$ corr. class. & \multicolumn{2}{|c|}{$\begin{array}{l}.281 ; .374 \\
74.2 \%\end{array}$} & \multicolumn{2}{|c|}{$\begin{array}{l}.199 ; .267 ; \\
70.2 \%\end{array}$} & \multicolumn{2}{|c|}{$\begin{array}{l}.291 ; .390 ; \\
75.2 \%\end{array}$} \\
\hline \multicolumn{7}{|l|}{ Step 3} \\
\hline Constant & -1.480 & .000 & -.864 & .154 & -1.421 & .004 \\
\hline Age & .050 & .000 & .032 & .125 & .055 & .001 \\
\hline Gender & -.351 & .000 & -.268 & .233 & -.759 & .000 \\
\hline Attitudes & .225 & .000 & .210 & .000 & .234 & .000 \\
\hline Subjective norms & .104 & .035 & -.322 & .012 & .058 & .590 \\
\hline Perceived behavioral control & .014 & .014 & -.003 & .839 & .000 & .997 \\
\hline $\mathrm{EE}$ & .098 & .000 & .091 & .048 & .124 & .024 \\
\hline $\mathrm{EE} *$ Attitudes & .000 & .936 & -.006 & .527 & .008 & .459 \\
\hline $\mathrm{EE} *$ Subj. norms & .001 & .958 & .058 & .281 & -.131 & .047 \\
\hline $\mathrm{EE} * \mathrm{PBC}$ & .001 & .502 & .006 & .324 & .000 & .968 \\
\hline$C \& S-R^{2} ;$ Nagelk. $\mathrm{R}^{2} ; \%$ corr. class. & \multicolumn{2}{|c|}{$\begin{array}{l}.287 ; .382 \\
75.1 \%\end{array}$} & \multicolumn{2}{|c|}{$\begin{array}{l}.209 ; .280 \\
70.4 \%\end{array}$} & \multicolumn{2}{|c|}{$\begin{array}{l}.299 ; .400 \\
76.5 \%\end{array}$} \\
\hline
\end{tabular}


evidence with regard to different conditions, such as motivational drivers and type of prior education.

EE seems to positively affect EI when controlled for age, gender, and motivational drivers. This finding is in line with theory and previous findings (Souitaris et al., 2007; Kolvereid and Moen, 1997), and underscores the importance of EE for educators and policy makers seeking to enhance EI. We note two issues, as follows.

First, the coefficients for EE-while positive and significant in all cases-are rather low. This may indicate that the didactics of EE could be improved. The search for the most effective didactic forms for $\mathrm{EE}$ is ongoing. The current situation is marked by little consensus on the type of didactics necessary to deliver the most effective EE (Martin et al., 2013), and by new emerging forms of EE (Xanthopoulou and Papagiannidis, 2012; Harms, 2015). Second, our findings indicate that business students may profit more from EE, as indicated by the larger coefficient. This lends support to the "Matthew effect" thesis in EE (Walberg and Tsai, 1983). This thesis postulates a positive impact of prior educational background, current education, and motivation on academic achievements. Students who have previously received a business education are therefore more likely to acquire and process knowledge related to entrepreneurship.

If it is recent engineering graduates whose entrepreneurial activities create new, high-quality firms (Åstebro et al., 2012), then our findings give cause for concern. While the level of EE for science and engineering students is significantly higher than for business students, in absolute terms it is still quite low. It also seems that current EE is less effective in raising their level of EI, potentially based on the "Matthew effect" in education. As extending the time commitment for EE is not often an option, we suggest that educators should investigate whether they can create EE didactics that tap into the cognitive schemata of science and engineering students. One promising contender may be the LeanStartup based classes (Harms, 2015; Harms et al., 2015), as this didactic approach draws heavily on the empirical circle (Ries, 2011) that all science and engineering students should be familiar with. The same approach also builds on the design approach that science and engineering students ought to be familiar with (Mueller and Thoring, 2012).

The effectiveness of EE does not seem to be affected by most TPB aspects, as we only find one moderating relationship. Hence, we find that EE is also effective for students with a TPB set that is initially unfavorable to EI. This is in line with the findings of Rauch and Hulsink (2015), who showed that EE may change TPB aspects in the course of education, as it positively affects attitudes and perceived behavioral control. However, we did not learn much about the conditions under which EE is more effective. Bae et al. (2014) examined other likely moderators of the EE-EI relationship-such as the specificity of the education, its duration, and the gender, family background, and culture of the students-and found that only supportive cultural contexts positively affected the EE-EI relationship.

One moderation was significant: that of EE and subjective norms for business students. We hypothesized that the greater the extent of EE, the weaker the positive impact of subjective norms on EI would be. We expect that the role models presented in EE education may actually outweigh the impact of the subjective norms affecting students. This would account for the negative coefficient.

While not central to this study, the results of the analysis of the direct effects of TPB drivers warrant discussion. While the positive relationship between pro-entrepreneurial attitudes and EI was expected, three findings stand out. First, the negative impact of subjective norms on the EI of science and engineering students warrants explanation. The more strongly their peers value entrepreneurship, the more determinedly science and engineering students reject entrepreneurship. The phenomenon might be explained by social identity theory (Obschonka et al., 2012), and by the notion that science and engineering students construct a social identity for themselves that is science-driven and not necessarily entrepreneurial (Jungert, 2013). Group members can react defensively to threats to their social identity (Branscombe et al., 1999) in that they resist "perceived group differences in values, beliefs, and attitudes" (de Hoog, 2013, p. 362). Hence, science and engineering students may react adversely to social pressure in favor of entrepreneurialism, even when they take courses in entrepreneurship. It follows that educators should strive to counter the threat posed by social identity, perhaps by including teaching on how entrepreneurialism is central to the identity of science and engineering students, for example by highlighting successful engineer-entrepreneur role models (Sun and Lo, 2012).

Second, the missing connection between "subjective norms" and EI for the full sample may be the source of methodological artifacts. This might be a result of balancing the positive and negative effects of subsamples (e.g., science and engineering students versus business students). Alternatively, it might be the result of a confounding effect: as subjective norms, attitudes, and EI are positively correlated, part of the effect of subjective norms on EI may be masked (for a similar observation see Schlaegel and Koenig, 2014). Third, the absence of the expected impact of "perceived behavioral control" could be explained by the fact that the items available to the research reflected a general locus of internal control, rather than a domain-specific construct. Using a more general measure tends to reduce predictive power (Chen et al., 1998). Domain-specific alternatives for future studies could be entrepreneurial self-efficacy (Chen et al., 1998) or a domain-specific locus of control scale (Schjoedt and Shaver, 2012).

The findings of this study must be viewed in light of its limitations. First, as we use a cross-sectional design, the temporal nature of causeand-effect cannot be incorporated in the models. We suggest pre- and post-test designs on the antecedents, processes, and effects of EE on EI (Rauch and Hulsink, 2015). Second, the effectiveness of EE is highly dependent on the particular didactics that are used. By pooling data from 23 universities, with an even larger variety of entrepreneurship courses, we were able to show a general trend. However, the effect of particular didactics on EI merits further inquiry. Third, although the tests implemented did not indicate any issues arising from the response rate, it was rather low, and we cannot completely discount the threat that the respondents may have self-selected into the survey as well as into EE. Fourth, we need to point out the time lag between the formation of EI and its translation into entrepreneurial action. Although recent engineering graduates have been shown to create high-quality new firms (Åstebro et al., 2012), the average age of the founders is in the mid-thirties. This creates a considerable time gap, and we have yet to see if the EI of students translates into higher startup rates among more mature adults.

Finally, when assessing the effectiveness of EE, the intention-action gap in entrepreneurship has to be taken into account. A recent longitudinal study in the same geographic context, also relying on the theoretical framework of the TPB, showed that within a one-year time frame only about $30 \%$ of intenders took steps toward entrepreneurship (Kautonen et al., 2015). In another study, the same authors identified action fear, action uncertainty, and competing interests as the main barriers against turning EI into entrepreneurial action (van Gelderen et al., 2013). These volitional factors can be addressed by EE.

The findings and limitations of the current research present a number of promising opportunities for future research. While highlighting the general effectiveness of $\mathrm{EE}$, the findings also reveal the need for didactic approaches in EE to be tailored to the specific needs of distinct groups of students. However, educators could only develop such targetgroup specific didactics in EE if they had a profound understanding of the challenges and barriers these specific target groups face in developing EI, and also of the issues involved in translating them into entrepreneurial action. Progressing to that level of understanding would require far more research to be conducted, particularly in a form based on longitudinal studies tracking students for a considerable time beyond the end of their formal EE. Research on entrepreneurship in later phases of life shows that general education has a long-term impact on entrepreneurship (Hatak et al., 2013, 2015; Harms et al., 2014). Thus, EE might also be expected to show such long-term effects. 
The results presented in this paper offer some justification for the importance many universities attach to EE. The findings suggest that $\mathrm{EE}$ is generally effective for both business students and science and engineering students. However, differences between business students and science and engineering students are evident with regard to the impact of subjective norms on EI: while subjective norms have a negative impact on science and engineering students' EI, this effect is not present in the business student sample. This result implies that EE should be target-group specific and thus address the issue of subjective norms separately for business students and science and engineering students.

\section{References}

Ajzen, I., 1991. The theory of planned behaviour. Organ. Behav. Hum. Decis. Process. 50, 179-211.

Åstebro, T., Bazzazian, N., Braguinsky, S., 2012. Startups by recent university graduates and their faculty: implications for university entrepreneurship policy. Res. Policy 41, 663-677.

Autio, E., Keeley, R.H., Klofsten, M., Ulfstedt, T., 1997. Entrepreneurial intent among students: testing an intent model in Asia, Scandinavia, and USA. In: Sexton, D.L., Kasarda, J.D. (Eds.), Frontiers of Entrepreneurial Research. Babson College Publications, Babson, MA.

Autio, E., Keeley, R.H., Klofsten, M., Parker, G.G.C., Hay, M., 2001. Entrepreneurial intent among students in Scandinavia and in the USA. Enterp. Innov. Manag. Stud. 2, $145-160$.

Bae, T.J., Qian, S., Miao, C., Fiet, J.O., 2014. The relationship between entrepreneurship education and entrepreneurial intentions: a meta-analytic review. Enterp. Theory Pract. 38, 217-254.

Bandura, A., 1986. Social Foundations of Thought and Action: A Social Cognitive Theory. Prentice-Hall, Englewood Cliffs.

Becker, G.S., 1964. Human Capital: A Theoretical and Empirical Analysis, with Special Reference to Education. National Bureau of Economic Research, New York, N.Y.

Bjornali, E.S., Støren, L.A., 2012. Examining competence factors that encourage innovative behaviour by European higher education graduate professionals. J. Small Bus. Enterp. Dev. 19, 402-423.

Branscombe, N., Ellemers, N., Spears, R., Doosje, B., 1999. The context and content of social identity threat. In: Ellemers, N., Spears, R., Doosje, B. (Eds.), Social Identity: Context, Commitment, Content. Blackwell, Oxford, UK, pp. 35-58.

Cantillon, R., 1931. Essai sur la nature du commerce en général, ed. and with an English translation by Henry Higgs for the Royal Economic Society. Macmillan \& Co. London.

Chang, S.-J., 2010. A.v. Witteloostuijn, L. Eden, From the editors: common method variance in international business research. J. Int. Bus. Stud. 41, 178-184

Chen, Y., 2010. Does entrepreneurship education matter to students' entrepreneurial intention? A Chinese perspective. Second International Conference on Information Science and Engineering, China.

Chen, C.C., Greene, P.G., Crick, A., 1998. Does entrepreneurial self-efficacy distinguish entrepreneurs from managers? J. Bus. Ventur. 13, 295-316.

Cotrugli, B., 1990. Il Libro Dell'Arte di Mercatura, a Cura di Ugo Tucci, Arsenale.

Davidsson, P., 2008. The Entrepreneurship Research Challenge. Edward Elgar, Cheltenham.

de Hoog, N., 2013. Processing of social identity threats: a defense motivation perspective. Soc. Psychol. 44, 361-372.

Dyer Jr., W.G., 1994. Toward a theory of entrepreneurial careers. Enterp. Theory Pract. 19, $7-21$.

Fayolle, A., Linan, F., 2014. The future of research on entrepreneurial intentions. J. Bus. Res. 67, 663-666

Fink, M., Lang, R., Harms, R., 2012. Local responses to global technological change - contrasting restructuring practices in two rural communities in Austria. Technol. Forecast. Soc. Chang. 80, 243-252.

Frederick, W., Walberg, J., 1980. Learning as a function of time. J. Educ. Res. 73.

Gorman, G., Hanlon, D., King, W., 1997. Some research perspectives on entrepreneurship education, enterprise education, and education for small business management: a ten-year literature review. Int. Small Bus. J. 15, 56-77.

Grichnik, D., Harms, R., 2007. Zur Zukunft der deutschsprachigen Entrepreneurshipforschung - Strategien und thematische Schwerpunkte. Zeitschrift für Klein- und Mittelunternehmen und Entrepreneurship 55, 266-275.

Harms, R., 2015. Self-regulated learning, team learning and project performance in entrepreneurship education: learning in a lean startup environment. Technol. Forecast. Soc. Chang. 100, 21-28.

Harms, R., Wdowiak, M., Schwarz, E.J., 2010. The role of entrepreneurship- and technology transfer oriented initiatives in improving the innovation system in the Western Balkans. Int. J. Bus. and Globalization 4, 18-34.

Harms, R., Kraus, S., Luck, F., Walsh, S.T., 2014. On the motivational drivers of gray entrepreneurship: an exploratory study. Technol. Forecast. Soc. Chang. 89, 358-365.

Harms, R., Marinakis, Y., Walsh, S.T., 2015. Lean Startup for materials ventures and other science-based ventures: Under what conditions is it useful? Trans. Mater. Res. 2. http://dx.doi.org/10.1088/2053-1613/2/3/035001.

Harrison, D.A., McLoughlin, M.E., Coalter, T.M., 1996. Context, cognition and common methode variance: psychometric and verbal protocol evidence. Organ. Behav. Hum. Decis. Process. 68, 246-261.

Hatak, I., Kautonen, T., Fink, M., 2013. Senior-Unternehmertum: Empirische Evidenz aus 27 europäischen Ländern. Die Betriebswirtschaft 73, 7-26.
Hatak, I., Harms, R., Fink, M., 2015. Age, job identification, and entrepreneurial intention. J. Manag. Psychol. 30.

Heitor, M., Horta, H., Mendonça, J., 2014. Developing human capital and research capacity: science policies promoting brain gain. Technological Forecasting and Social Change 82, 6-22.

Ho, Y.-P., Low, P.-C., Wong, P.-K., 2014. Do university entrepreneurship programs influence students' entrepreneurial behavior? An empirical analysis of university students in Singapore. Advances in the Study of Entrepreneurship, Innovation, and Economic Growth 24, 65-87.

Jungert, T., 2013. Social identities among engineering students and through their transition to work: a longitudinal study. Stud. High. Educ. 38, 39-52.

Kahneman, D., Tversky, A., 1979. Prospect Theory: An Analysis of Decision Under Risk Econometrica, XL. pp. 263-291.

Kailer, N., Gruber-Mücke, T., Wimmer-Wurm, B., Blanka, C., 2012. Entrepreneurial Intentions and Activities of Students at Austria Universities - Global University Entrepreneurial Spirit Student's Survey 2011 - National Report. Johannes Kepler University Linz.

Kautonen, T., van Gelderen, M., Fink, M., 2015. Robustness of the theory of planned behaviour in predicting entrepreneurial intentions and action. Enterp. Theory Pract. 39 655-674.

Kirchhoff, B.A., 1994. Entrepreneurship and dynamic capitalism. The Economics of Business Firm Formation and Growth, Praeger, Westport, Conn.,

Kirchhoff, B.A., Linton, J.D., Walsh, S.T., 2013. Neo-Marshallian equilibrium versus Schumpeterian creative destruction: its impact on business research and economic policy. J. Small Bus. Manag. 51, 159-166.

Kolvereid, L., 1996. Prediction of employment status choice intentions. Enterp. Theory Pract. 21, 47-57.

Kolvereid, L., Moen, O., 1997. Entrepreneurship among business graduates: does a majo in entrepreneurship make a difference? J. Eur. Ind. Train. 21, 154-160.

Krueger, N.F., Brazeal, D.V., 1994. Entrepreneurial potential and potential entrepreneurs. Enterp. Theory Pract. 18, 91-104.

Krueger, N.F., Carsrud, A.L., 1993. Entrepreneurial intentions: applying the theory of planned behaviour. Entrep. Reg. Dev. 10, 315-330.

Krueger, N.F., Reilly, M.D., Carsrud, A.L., 2000. Competing models of entrepreneurial intentions. J. Bus. Ventur. 15, 411-432.

Kuckertz, A., Wagner, M., 2010. The influence of sustainability orientation on entrepreneurial intentions - investigating the role of business experience. J. Bus. Ventur. 25, 524-539.

Kuehn, K.W., 2008. Entrepreneurial intentions research: implications for entrepreneurship education. J. Entrep. Educ. 11, 87-98.

Kuratko, D.F., 2005. The emergence of entrepreneurship education: development, trends, and challenges. Enterp. Theory Pract. 29, 577-597.

Levenson, H., 1973. Reliability and validity of the I, P, and C scales - a multidimensiona view of locus of control. American Psychological Association Convention, Montreal.

Liñán, F., 2004. Intention-based models of entrepreneurship education. Piccola Impresa/ Small Bus. 3, 11-35.

Lindell, M., Karagozoglu, N., 1997. Global strategies of US and Scandinavian R\&D-intensive small- and medium-sized companies. Eur. Manag. J. 15, 92-100.

Lüthje, C., Franke, N., 2003. The "making" of an entrepreneur: testing a model of entrepreneurial intent among engineering students at MIT. R\&D Manag. 32, 135-147.

Martin, B.C., McNally, J.J., Kay, M.J., 2013. Examining the formation of human capital in entrepreneurship: a meta-analysis of entrepreneurship education outcomes. J. Bus. Ventur. 28, 211-224

Mueller, R.M., Thoring, K., 2012. Design thinking vs. lean start up: a comparison of two user-driven innovation strategies. International Design Management Research Conference, Boston, MA

Obschonka, M., Goethner, M., Silbereisen, R.K., Cantner, U., 2012. Social identity and the transition to entrepreneurship: the role of group identification with workplace peers. J. Vocat. Behav. 80, 137-147.

Phan, P., Siegel, D., Wright, M., 2009. New developments in technology management education: background issues, program initiatives, and a research agenda. Acad. Manag. Learn. Educ. 8, 324-336.

Podsakoff, P.M., MacKenzie, S.B., Podsakoff, N.P., Lee, J.-Y., 2003. Common method biases in behavioral research: a critical review of the literature and recommended remedies. J. Appl. Psychol. 88, 879-903.

Pruett, M., Shinnar, R., Toney, B., Llopis, F., Fox, J., 2009. Explaining entrepreneurial intentions of university students: a cross-cultural study. Int. J. Entrep. Behav. Res. 15, 571-594.

Rauch, A.J., Hulsink, W., 2015. Putting entrepreneurship education where the intention to act lies. An Investigation into the Impact of Entrepreneurship Education on Entrepreneurial Behaviour, Academy of Management Learning \& Education http://dx.doi.org/ 10.5465/amle.2012.0293.

Rauch, A., Frese, M., Utsch, A. 2005. Effects of human capital and long-term human resources development and utilization on employment growth of small-scale businesses: a causal analysis. Enterp. Theory Pract. 29, 681-698.

Richardson, H., Simmering, M., Sturman, M., 2009. A tale of three perspectives: examining post hoc statistical techniques for detection and correction of common method variance. Organ. Res. Methods 12, 762-800.

Ries, E., 2011. The Lean Startup. Crown Publishing, New York.

Robinson, P.B., Stimpson, D.V., Huefner, J.C., Hunt, H.K., 1991. An attitude approach to the prediction of entrepreneurship. Enterp. Theory Pract. 15, 13-31.

Rogelberg, S.G., Stanton, J.M., 2007. Introduction: understanding and dealing with organizational survey nonresponse. Organ. Res. Methods 10, 195-209.

Rogelberg, S.G., Conway, J.M., Sederburg, M.E., Spitzmüller, C., Aziz, S., Knight, W.E., 2003. Profiling active and passive nonrespondents to an organizational survey. J. Appl Psychol. 88, 1104-1114.

Schjoedt, L., Shaver, K.G., 2012. Development and validation of a locus of control scale for the entrepreneurship domain. Small Bus. Econ. 39, 713-726. 
Schlaegel, C., Koenig, M., 2014. Determinants of entrepreneurial intent: a meta-analytic test and integration of competing models. Enterp. Theory Pract. 38, 291-332.

Schumpeter, J., 1912. Theorie der Wirtschaftlichen Entwicklung. Duncker \& Humblot, Leipzig.

Segal, G., Borgia, D., Schoenfeld, J., 2005. The motivation to become an entrepreneur. Int. J. Entrep. Behav. Res. 11, 42-57.

Sieger, P., Fueglistaller, U., Zellweger, T., 2011. International Report GUESSS 2011, in, GUESSS, St. Gallen,.

Simon, H.A., 1979. Information processing models of cognition. Annu. Rev. Psychol. 30 363-396.

Souitaris, V., Zerbinati, S., Al-Laham, A., 2007. Do entrepreneurship programmes raise entrepreneurial intention of science and engineering students? The effect of learning, inspiration and resources. J. Bus. Ventur. 22, 566-591.

Spector, P.E., 2006. Method variance in organizational research: truth or urban legend? Organ. Res. Methods 9, 221-232.

Sun, H., Lo, C.C.T., 2012. Impact of role models on the entrepreneurial intentions of engineering students. IEEE International Conference on Teaching, Assessment, and Learning for Engineering, Hong Kong.

Swan, W., Chang-Schneider, C., McClarity, K., 2007. Do people's self-views matter? Am. Psychol. 62, 84-94.

Thompson, E.R., 2009. Individual entrepreneurial intention: construct clarification and development of an internationally reliable metric. Enterp. Theory Pract. 33, 669-694.

Unger, J., Rauch, A., Frese, M., Rosenbusch, N., 2011. Human capital and entrepreneurial success: a meta-analytical review. J. Bus. Ventur. 26, 341-358.

van der Zwan, P., Verheul, I., Thurik, A.R., 2012. The entrepreneurial ladder, gender, and regional development. Small Bus. Econ. 39, 627-643.

Van Gelderen, M., Jansen, P., 2008. Autonomy as a start-up motive. J. Small Bus. Enterp. Dev. 13, 23-32.

van Gelderen, M, Kautonen, T., Fink, M., 2013. The moderating role of volitional conditions and trait self-control on the entrepreneurial intention-action relationship. Babson College Entrepreneurship Research Conference, Lyon.

Walberg, H.J., Tsai, S.-L., 1983. 'Matthew' effects in education. Am. Educ. Res. J. 20 359-373.

Williams, L.J., Brown, B.K., 1994. Method variance in human resource research: effects on correlations, path coefficients, and hypothesis testing. Organ. Behav. Hum. Decis. Process. 57, 185-209.

Xanthopoulou, D., Papagiannidis, S., 2012. Play online, work better? Examining the spillover of active learning and transformational leadership. Technol. Forecast. Soc. Chang. $79,1328-1339$

Yanez, M., Khalil, T.M., Walsh, S.T., 2010. IAMOT and education: defining a technology and innovation management (TIM) body-of-knowledge (BoK) for graduate education (TIM BoK). Technovation 30, 389-400.
Yu, J., Cooper, H., 1983. A quantitative review of research design effects on response rates to questionnaires. J. Mark. Res. 20, 36-44.

Dr. Daniela Maresch is Assistant Professor at the Institute for Innovation Management (IFI) at the Johannes Kepler University Linz. After her studies in International Business at WU Vienna University of Economics and Business and at ESC Lyon (France) Daniela gained a PhD from WU Vienna and WWU Münster (Germany). Daniela gained practical experience in financial reporting working for a major Austrian utility. Due to her interest in legal topics, Daniela completed an LLM. (WU) in Business Law while working as a Senior Lecturer at the Department of Finance, Accounting and Statistics of WU Vienna. Before joining the IFI team in March 2014, Daniela worked in corporate law for a renowned Viennese law firm. Daniela has published in the area of auditing and financial reporting and will now employ her interdisciplinary expertise in research into topics at the intersection of innovation, finance and business law. Her research at the IFI will focus on the role of trust in bank lending, the social impact of disruptive technologies such as additive manufacturing and the protection of intellectual property rights in business angel investments.

PD Dr. Rainer Harms is Associate Professor for Entrepreneurship at NIKOS, University of Twente, where he is heading the research direction of International Entrepreneurship. $\mathrm{He}$ is Associate Editor of Creativity and Innovation Management and Zeitschrift für KMU und Entrepreneurship. He was visiting professor at the Vienna University of Economics and Business (Wirtschaftsuniversität Wien), and at the Universitat Autònoma de Barcelona, and held positions at University Klagenfurt (Habilitation) and WWU Münster (Doctorate). His research interests are technology entrepreneurship, firm growth, and innovation management.

Prof. Dr. Norbert Kailer is Full Professor and Head of the Institute for Entrepreneurship and Organizational Development at Johannes Kepler University Linz (JKU) and member of the board of the academic pre-incubator Akostart in Linz. He was professor for HRM at the Institute for Work Science at the Ruhr-University Bochum. Research interests: development of SME, entrepreneurship education, university-business cooperation, and technology entrepreneurship.

Mag. Birgit Wimmer-Wurm is university assistant at the Institute for Entrepreneurship and Organizational Development at JKU Linz. Currently she is JKU program manager for the Federal Program "Knowledge Transfer Centers and Exploitation of IPR - Knowledge Transfer Centre West”. Research interests: technology and knowledge transfer. 